Original Article

\title{
An evaluation of the effect ov lanolin in healing nipple injuries*
}

\author{
Avaliação do efeito da lanolina na cicatrização dos traumas mamilares \\ La evaluación del efecto de la lanolina en la cicatrización de los traumas del pezön
}

Kelly Pereira Coca ${ }^{1}$, Ana Cristina Freitas de Vilhena Abrão ${ }^{2}$

\begin{abstract}
Objective: To evaluate the effect of anhydrous lanolin-based ointment in the process of healing nipple injuries. Methods: This is a descriptive experimental study was performed in two Maternity Hospitals in Sao Paulo. The random sample consisted of 50 puerperium women with nipple injuries, hospitalized in the period of June 2002 to July 2003. Participants were randomly assigned into control and experimental groups, by the means of a draw. Statistical analysis was performed using Qui-square, Student's t test, and ANOVA (á at $5 \%$ ).Results: The size of the injury in the control group reduced in $0.41 \pm 0.11 \mathrm{~cm}$ (right breast) and $0.29 \pm 0.06 \mathrm{~cm}$ (left breast) compared to the experimental group, from the first to the second evaluation $(\mathrm{p}<0.001)$, showing to be statistically significant.
\end{abstract}

Conclusion: The lanolin is effective in treating nipple injuries.

Keywords: Nipples/injuries; Wound healing/drug effects; Lanolin/therapeutic use; Breastfeeding/adverse effects

\section{RESUMO}

Objetivo: Avaliar o efeito da pomada a base de lanolina anídrica na cicatrização de lesões mamilares apresentadas por puérperas internadas em duas maternidades do Município de São Paulo. Métodos: Estudo experimental descritivo realizado em duas maternidades do Município de São Paulo. A amostra aleatória foi constituída de 50 puérperas com trauma mamilar internadas no período de junho de 2002 a julho de 2003. A amostra foi composta por meio de sorteio aleatório, distribuída entre os grupos controle e experimental. Utilizou-se testes Quiquadrado, t de Student e ANOVA (á of 5\%). Resultados: Observou-se uma diferença na diminuição do tamanho da lesão mamilar de 0,41 $\pm 0,11 \mathrm{~cm}$ (mama direita) e 0,29 $\pm 0,06 \mathrm{~cm}$ (mama esquerda) nas puérperas do grupo experimental para o grupo controle, da primeira para a segunda avaliação $(\mathrm{p}<0,001)$, mostrando ser estatisticamente significativa. Conclusão: A lanolina foi favorável no tratamento das lesões mamilares.

Descritores: Mamilos/lesões; Cicatrização de feridas/efeitos de drogas; Lanolina/uso terapêutico; Aleitamento materno/efeitos adversos

\section{RESUMEN}

Objetivo: Evaluar el efecto de la pomada a base de lanolina anhídrica en la cicatrización de lesiones del pezón. Métodos: Estudio experimental descriptivo realizado en dos Maternidades de la ciudad de Sao Paulo. La muestra aleatoria estuvo conformada por 50 puérperas con trauma del pezón internadas en el período de junio del 2002 a julio del 2003. La muestra fue compuesta por medio de sorteo aleatorio y distribuida entre los grupos control y experimental. Se utilizó el Chi Cuadrado, t de Student y ANOVA (á del 5\%). Resultados: Se observó una diferencia en la reducción del tamaño de la lesión del pezón de 0.41 que $\pm 0,11 \mathrm{~cm}$ (mama derecha) y 0,29 $\pm 0.06 \mathrm{~cm}$ (mama izquierda) en las puérperas del grupo experimental en relación al grupo control, de la primera a la segunda evaluación $(\mathrm{p}<0,001)$, demostrando ser estadísticamente significativa. Conclusión: La lanolina es favorable en el tratamiento de las lesiones del pezón.

Descriptores: Pezones/lesiones; Cicatrización de heridas/efectos de drogas; Lanolina/uso terapéutico; Lactancia materna/efectos adversos

\footnotetext{
* This article was written based on the monograph: A Study on the Effects of Lanolin in the Treatment of Nipple Injuries; presented in the nursing specialization course of the Department of Nursing at the Universidade Federal de São Paulo (UNIFESP) - São Paulo, Brazil.

${ }^{1}$ MSc; Obstetric Nurse; Universidade Federal de São Paulo - UNIFESP - São Paulo (SP), Brażil.

${ }^{2}$ Doctor Professor of the Obstetric Nursing Discipline - Department of Nursing at the Universidade Federal de São Paulo (UNIFESP) - São Paulo, Brazil.
} 


\section{INTRODUCTION}

Breastfeeding reduces perinatal morbidity and mortality ${ }^{(1)}$, protects the child against infections in the first year of life and against chronic diseases in adult age ${ }^{(2)}$. Many complications hinder the success of this practice. One of these complications is nipple trauma, which consists of one of the main reasons of early weaning ${ }^{(3-7)}$. Inadequate child handling and positioning is among the factors that predispose the appearance of nipple injuries ${ }^{(8-13)}$.

Nipple trauma is defined as a discontinuity of nipple $\operatorname{skin}^{(3)}$. Concomitant with the identification and correction of causal factors, different treatments are recommended to provide pain relief and quick healing ${ }^{(6-7,10)}$. The conducts to treat nipple trauma described in literature are not specific to the many kinds of injuries. These treatments can be divided in protection measures, like alternation of positions in breastfeeding and using shells; dry treatments, like using a dryer, and sun or light bathing; and wet treatments, like using breast milk, creams, ointments, lotions, and salves ${ }^{(14)}$. Despite controversial indications between researchers on the subject, there is not scientific evidence of any method to treat nipple injury. Thus, it remains a great challenge for professionals of the field.

Lanolin has been recommended for healing nipple traumas due to its effect on the formation of a barrier that avoids losing the natural moistness of deeper skin layers, and thus increases cellular growth ${ }^{(3,5,9,14)}$. In Brazil, it use is being increasingly disseminated, and it is becoming routine in the treatment of nipple injuries in most of private hospitals. Modified anhydrous lanolin - USP (renamed simply as lanolin by "United States Pharmacopeia", in 1992) is a highly purified compound, hypoallergenic, tasteless, odorless, and with low levels of pesticide (it contains less than $1 \mathrm{ppm}$ of any kind of pesticide and not more than $3 \mathrm{ppm}$ in total). Therefore, it is indicated to stimulate the healing process and pain relief. It is adequate for the absorption by the mucous membrane and/ or by ingestion. In other words, there is no need to remove it before breastfeeding ${ }^{(6,10,15)}$.

\section{OBJECTIVE}

To evaluate the anhydrous lanolin-based salve effects in the healing of nipple injuries in hospitalized puerperal women of two maternities in the city of São Paulo.

\section{METHODS}

This experimental study was performed in
Rooming-in Care Units of two maternities in the city of São Paulo. The convenience sample was obtained in the data collection period. The sample consisted of 50 puerperal women hospitalized between June 2002, and July 2003. Subjects were eligible if diagnosed with unilateral or bilateral nipple trauma, having normal children, in term, and were exclusively in maternal breastfeeding. Participants with inversed or pseudoinverted nipples in, at least, one nipple, and mothers of twins were excluded from the study. The puerperal women were randomly assigned to the control or experimental group by numbering their beds. To obtain homogeneity in the groups, all the women received instruction about how to position the baby and appropriate handling of the nipple-areola region during breastfeeding. The mothers' variables studied were skin color, age, schooling, parity, delivery type, previous breastfeeding experience, type of nipple, and nipple trauma. Concerning the child, the studied data were gender and birth weight.

The trauma was identified by the presence of any lesions on the nipple's skin, according to the definition by Vinha, and evaluated by measuring its extension ${ }^{(12)}$. Usually, the lesion reaches the dermis and epidermis, and shows itself as a linear or curved ulceration. The authors chose not to differentiate the various types of traumas, because there is no consensus among authors about the degree of harm to the nipple-areola tissue. The data collection instrument was designed specifically for the study, and had been previously tested.

The data collection was initiated in June 2002, after the project had been approved by the Research Ethics Committee of the Federal University of São Paulo, authorization obtained from the hospital institutions, and written consent obtained from all the participants, being concluded in July 2003. Two nursing consultations to the mother and newborn, with a 24 -hour interval, were performed.

In the first consultation, the 26 women in the control group as well as the 24 in the experimental group were evaluated in terms of child positioning and the prehension of the nipple-areola region during breastfeeding. In case the technique was wrong, the researcher gave corrective instructions and observed, again, until it was sure the child was being correctly breastfed.

After breastfeeding was over, each nipple's lesion was measured using a magnifying glass and measuring tape. The size of the lesion, in centimeters, was recorded on a specific form. Women in the control were instructed to perform the routine clinical procedures, i.e., using breast milk in the nipple-areola region and in the lesion area, before and after breastfeeding. Women in the experimental group receive instructions to use lanolin salve instead of breast milk on the lesions, as recommended 
by the manufacturer: after each breastfeeding, put a little quantity of the salve on the fingertip, spread a thin layer in the nipple and lesion region, and ventilate until completely dry.

In the second consultation, the aforementioned procedures were performed. The data was analyzed using Chi-Square, Student T Test and Analysis of Variance (ANOVA), with repeated measure, according to the type of variable involved. A 5\% significance level was adopted, i.e., results were significant for $\mathrm{p}$ values inferior to $5 \%(\mathrm{P}<0.05)$.

\section{RESULTS}

The groups were studied applying statistical tests to evaluate the homogeneity and a posterior comparison was made (Table 1).

The women's age ranged between 15 and 42 years, with an average age of 25 years (SD 6.8). The groups were homogeneous concerning skin color, age, schooling, parity and previous breastfeeding experience, newborn's gender and birth weight $(\mathrm{P}>0.05)$.

Concerning delivery time, it was observed that the control group has a greater proportion of vaginal delivery compared to the experimental group $(p=0.025)$. Therefore, this factor was evaluated along with lesion behavior between consultations, with separate evaluations of the breasts.

Concerning the type of nipple, the control group had more cases of protruding nipples on both breasts $(p=0.001)$. However, since this was observed in women in the control group, in which the medicine was not tested, no further statistical tests were needed.

The analysis of the variable lesion location showed that $31(62 \%)$ mothers had bilateral lesion and 19 $(38 \%)$ had unilateral lesions. Regarding the former, $10(20 \%)$ presented lesion on the right breast, and 9 $(20 \%)$ on the left. For this reason, the breasts were evaluated individually, considering, therefore, 41 lesions on right (20 in the experimental group and 21 in the control group) and 40 lesions on left (24 in the experimental group and 16 in the control group).

\section{Right Breast}

The average lesion size on the right breast, across the consultations, was analyzed in relation to vaginal and cesarean deliveries (Figure 1), in the experimental and control groups. The lesion size did not remain constant between the two consultations, according to delivery type and group $(\mathrm{p}=0.007)$, but multiple comparisons were performed, which showed that in the control group there was no difference in lesion size, according to delivery type $(p=0.818)$. Similar results occurred in the experimental group $(\mathrm{p}=0.325)$, demonstrating that delivery type had no affect on lesion size.

To evaluate the effect of lanolin in the experimental group, the behavior of the right breast lesion size in both groups was compared across evaluations using

Table 1 - Study variables, as per control and experimental group

\begin{tabular}{lccc}
\hline Variable / Group & $\begin{array}{c}\text { Experimental } \\
(\mathrm{n}=24)\end{array}$ & $\begin{array}{c}\text { Control } \\
(\mathrm{n}=26)\end{array}$ & p - Value \\
\hline Skin Color & $15(62.5 \%)$ & $19(73.1 \%)$ & $0.423^{*}$ \\
White & $09(37.5 \%)$ & $07(26.9 \%)$ & \\
Non-white & $25.5 \pm 6.4$ & $25.4 \pm 7.2$ & $0.969^{* *}$ \\
\hline Age (years) & $8.6 \pm 2.8$ & $8.0 \pm 2.4$ & $0.423^{* *}$ \\
\hline Education (years of schooling) & $\mathbf{1 . 6 \pm 0 . 8}$ & $\mathbf{2 . 0} \pm 1.5$ & $\mathbf{0 . 1 7 9 * *}$ \\
\hline Parity & $10(41.7 \%)$ & $19(73.1 \%)$ & $0.025^{*}$ \\
\hline Delivery Type & $14(58.3 \%)$ & $07(26.9 \%)$ & \\
Vaginal & $10(41.7 \%)$ & $09(34.6 \%)$ & $0.608^{*}$ \\
Cesarian & $14(58.3 \%)$ & $17(65.4 \%)$ & \\
\hline Former Breastfeeding Experience & $13(54.2 \%)$ & $25(96.2 \%)$ & $0.001^{*}$ \\
Yes & $11(45.8 \%)$ & $01(3.8 \%)$ & \\
No & $14(58.3 \%)$ & $25(96.2 \%)$ & $0.001^{*}$ \\
\hline Right Nipple Type & $10(41.7 \%)$ & $01(3.8 \%)$ & \\
Protrusive & $12(50.0 \%)$ & $17(65.4 \%)$ & $0.271^{*}$ \\
Semiprotrusive & $12(50.0 \%)$ & $09(34.6 \%)$ & \\
\hline Left Nipple Type & $2958.5 \pm 524.0$ & $3132.9 \pm 526.1$ & $0.246^{* *}$ \\
Protrusive & & & \\
Semiprotrusive & &
\end{tabular}


ANOVA with repeated measures (Figure 2). According to the results, both groups did not have the same average lesion size across the consultations $(\mathrm{p}=0.003)$. Hence, it was evaluated if there was any difference between the consultations.

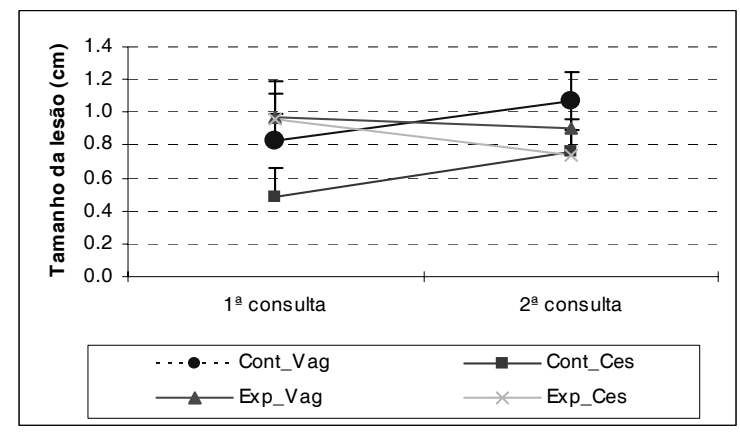

Figure 1 - Behavior of the right nipple lesion size, between first and second visits, according to group and delivery type.

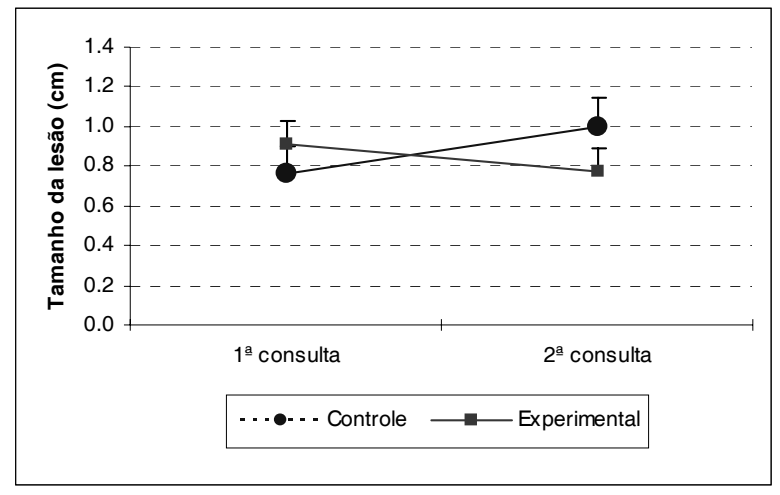

Figure 2 - Behavior of the right nipple lesion size, between first and second visits, according to group.

In the first consultation, the experimental group showed an average increase of $0.15 \pm 0.18 \mathrm{~cm}$ in the lesion size compared to the control group, but this difference was not statistically significant ( $p$ $=0.408)$. In the second consultation, the situation reversed, i.e., the control group showed, in average, a lesion size $0.22 \pm 0.18 \mathrm{~cm}$ larger than in the experimental group, but this difference was also not statistically significant $(\mathrm{p}=0.238)$. Comparing the difference in lesion size in the first and second consultations, there was lesions in the control group increased in $0.25 \pm 0.08 \mathrm{~cm}(\mathrm{p}=0.003)$. As for the experimental group, there was a reduction in lesion size of $0.160 .08 \mathrm{~cm}(p=0.064)$. Considering the lesion size between consultations and in each group, the average lesion size in the experimental group was $0.41 \pm 0.11 \mathrm{~cm}$ smaller than in the control group ( $p=0.001)$, which is considered statistically significant.

\section{Left Breast}

The analyses concerning the left breasts were similar to those of the right breasts (Figure 3). The lesion size did not remain constant throughout two consultations, considering the delivery type and group $(\mathrm{p}<0.001)$. However, after multiple comparisons, no difference was found in the lesion size of the left breast, related to delivery type in the control group $(p=0.764)$ nor for experimental group $(p=0.329)$. In other words, the type of delivery also had no affect on lesion size on the left breasts.

The effect of lanolin in the experimental group was evaluated using the same tests used for the evaluation of the right breasts (Figure 4). In the first consultation, the experimental group showed an average lesion size $0.36 \pm 0.24 \mathrm{~cm}$ larger than the control group, but this difference was not statistically significant $(\mathrm{p}=0.273)$.

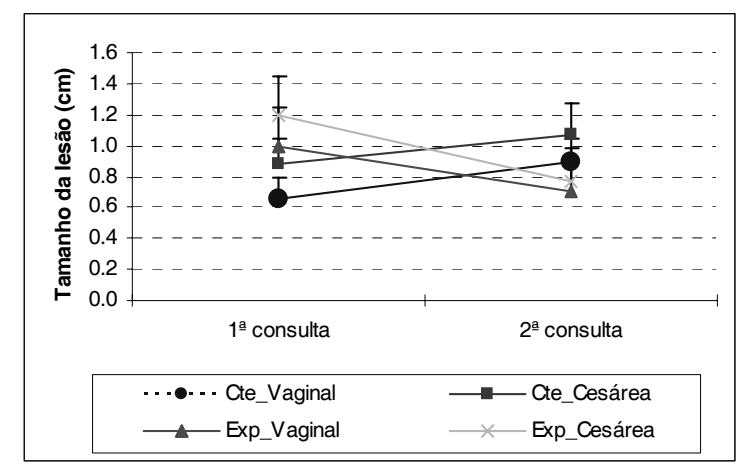

Figure 3 - Behavior of the left nipple lesion size, between first and second visits, according to group and delivery type.

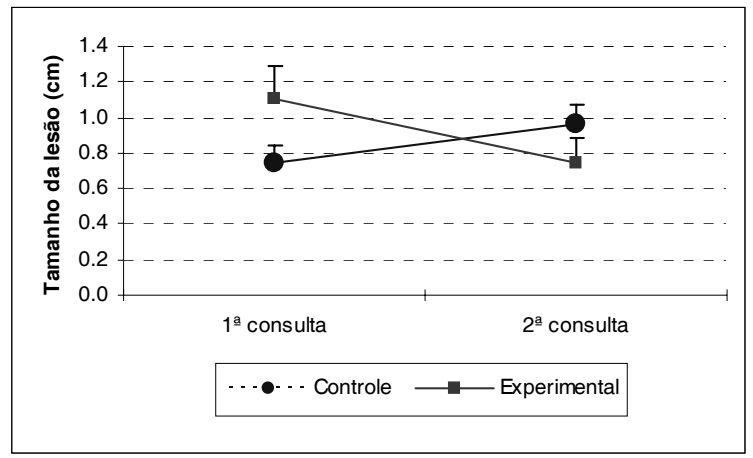

Figure 4 - Behavior of the left nipple lesion size, between first and second visits, according to group. 
A difference in lesion sizes was observed between consultations. In the control group, the lesion increased in $0.22 \pm 0.09 \mathrm{~cm}(\mathrm{p}=0.022)$, and in the experimental group the lesion reduced in 0.37 $\pm 0.08 \mathrm{~cm}(\mathrm{p}<0.001)$. This shows that the use of lanolin was statistically significant in reducing the lesion. Comparing the lesion size in the first and second consultations, for each group, it was observed that the lesion size in the experimental group was $0.29 \pm 0.06 \mathrm{~cm}$ smaller than the in the control group $(\mathrm{p}<0.001)$, which is considered statistically significant.

\section{DISCUSSION}

Studies have shown that nipple traumas occur with greater frequency in primiparae with a light complexion, with nipple anomalies, mothers of male newborns, and occur mainly in the first postpartum week $^{(11-12)}$. However, the women in the studied sample did not show any differences related to these variables. Using salve on the nipple area is contraindicated due to its interference in the bacteriostatic and lubrication properties, since it predisposes the occurrence of nipple trauma ${ }^{(12-13)}$. Some authors indicate the use of lanolin-based salve as a treatment, showing the positive effects in healing the nipple trauma. They justify its use stating that it creates a barrier that prevents deep skin layers from loosing their natural moisture, and increases the speed of epithelial cells proliferation, reducing the

\section{REFERENCES}

1. Effect of breastfeeding on infant and child mortality due to infectious diseases in less developed countries: a pooled analysis. WHO Collaborative Study Team on the Role of Breastfeeding on the Prevention of Infant Mortality. Lancet. 2000; 355(9202):451-5. Erratum in: Lancet 2000; 355(9209):1104. Comment in: Lancet. 2000; 355(9212):1370.

2. Bick D. The benefits of breastfeeding for the infant. Br J Midwifery. 1999; 7(5):312-9.

3. Tait P. Nipple pain in breastfeeding women: causes, treatment, and prevention strategies. J Midwifery Womens Health. 2000; 45(3):212-5.

4. Lavergne NA. Does application of tea bags to sore nipples while breastfeeding provide effective relief? J Obstet Gynecol Neonatal Nurs. 1997; 26(1):53-8. Comment in: J Obstet Gynecol Neonatal Nurs. 1997; 26(6):629-30.

5. Brent N, Rudy SJ, Redd B, Rudy TE, Roth LA. Sore nipples in breast-feeding women: a clinical trial of wound dressings vs conventional care. Arch Pediatr Adolesc Med. 1998; 152(11):1077-82. Comment in: Arch Pediatr Adolesc Med. 1999; $153(6): 658$. formation of dead tissue and crusts ${ }^{(3,5,9-10,14)}$, and thus it reduces healing time. Therefore, controversies exist regarding the indication or using these products, or not, when breastfeeding.

This study demonstrated that using anhydrous lanolin had statistically significant positive effects in nipple trauma treatment, since the women in the experimental group presented a reduction in the lesion size in the studied 24-hour period, providing a faster healing process compared to the control group.

The study also emphasized that the nipple lesions in the control group increased between the evaluations. This demonstrates that the nipples were still suffering integrity changes, while the lesions of women in the experimental group women improved, including lesions that, in the first evaluation, were larger than those of the women in the control group.

\section{CONCLUSION}

The present study had some limitations to obtain a larger sample. Nevertheless, it showed that the use of anhydrous lanolin was effective in treating nipple injuries, accelerating the healing process. Therefore, lanolin can be indicated to treat nipple traumas, and contributes to reducing the difficulties imposed to puerperal women while breastfeeding. Further studies should be conducted to discuss the types and severity of the lesions, and to suggest specific treatments.
6. Huml S. Sore nipples. A new look at an old problem through the eyes of a dermatologist. Pract Midwife. 1999; 2(2):28-31.

7. Coca KP. Traumas mamilares: estudo dos fatores associados. [Tese Mestrado]. São Paulo: Universidade Federal de São Paulo. Escola Paulista de Medicina; 2005.78p.

8. Lawrence RA, Lawrence RM. Breastfeeding: a guide for the medical profession. 5a ed. St. Louis: Mosby; 1999.

9. Bell KK, Rawlings NL. Promoting breast-feeding by managing common lactation problems. Nurse Pract. 1998; 23(6):102-4. 106, 109-10 passim.

10. Biancuzzo M. Sore nipples: prevention and problem solving. Herndon: WMC Wourldwide Publishing; 2000.

11. Mohrbacher N, Stock J. The breastfeeding answer book. Revised edition. Illinois: La Leche League International; 1997. p. 387-412.

12. Vinha VHP. O Livro da amamentação. São Paulo: Balieiro; 1999. p. 45-54.

13. Lana APB. O livro de estímulo à amamentação: uma visão biológica, fisiológica e psicológica comportamental da amamentação. São Paulo: Atheneu; 2001. p. 321-7. 
14. Giugliani ERJ. Falta embasamento científico no tratamento dos traumas mamilares. J Pediatr (Rio J). 2003; 79(3): 197-8.
15. Hagen RL. Lanolin for sore nipples. Arch Pediatr Adolesc Med. 1999; 153(6):658. 